\title{
Construction of marinas in the Croatian coastal cities of Split and Rijeka as attractive nautical destinations
}

\author{
S. Favro ${ }^{1} \&$ M. Kovačić ${ }^{2}$ \\ ${ }^{1}$ Faculty of Economics, University of Split, Croatia \\ ${ }^{2}$ Faculty of Maritime Studies, University of Rijeka, Croatia
}

\begin{abstract}
In the last ten years Croatian coastal cities and towns have been changing their landscape to a large extent. Port, shipbuilding and other activities have only a secondary role, while tourism has become an attractive activity in all of its aspects. Some parts of port areas have undergone a change of the original intended use, whereby nautical tourism has a special position.

This paper researches the development of two Croatian cities, Split and Rijeka, that are subject to significant and at the same time different changes. The authors analyse the current status of the development of nautical tourism in Croatia with an emphasis on Split and Rijeka. Physical planning is particularly analysed as well as the influence of public authorities on coastal landscaping.

The paper elaborates a methodological approach for selection of marina locations in the coastal area. By applying a multi-criteria analysis in the selection of marina locations in the cities of Split and Rijeka, the authors present the possibility of rational, sustainable use of coastal space. Taking into consideration cultural and other identities of an urban area, the authors emphasize the importance of a responsible and controlled redesign of the coastal area as an important factor for the life of citizens.
\end{abstract}

Keywords: nautical tourism, old city ports, space redesign, Croatia.

\section{Introduction}

Maritime ports are an integral part of large cities, their most attractive, and at the same time, their most profitable area. The development of ports in Croatia and in the Mediterranean has proceeded alongside the development of maritime towns. 
Their age parallels the age of the towns. Throughout history, city ports have changed their economic role and profile adapting to the needs of the market and cities. The development of nautical tourism has placed great pressure on old ports changing their existing profile. Over the centuries, city ports of large and mediumsize cities have performed the function of maritime traffic, transportation of persons and cargo, and trade.

Croatia still hasn't revitalized nautical tourism, especially the construction of major nautical centres in cities. Urban areas are attractive to boaters, so many nautical marinas are situated in major cities of the Mediterranean.

The cities of Split and Rijeka have an adequate port area which waters are suitable for the location of nautical marinas and acceptance of larger vessels. The aim of this paper is to think about the further development of city ports Split and Rijeka and the selection of nautical locations. The aim of this paper is also to determine advantages of the reassignment of the port area for boaters' needs on the example of the city of Split and Rijeka.

\section{Theoretical guidelines and analysis of the issue}

Nautical tourism around the world and in Europe is a phenomenon and tourism and economic activity which have registered a high rate of steady growth in the last decades. Its development can be scientifically observed through three fundamental forms: ports of nautical tourism charter and cruises. All these nautical tourism branches are reciprocally and closely linked to the destination, with its scenic spots and cultural heritage. In pursuing visits to scenic spots and learning about cultures of destinations, arrivals of nautical tourists, either by personal or rented yachts, as well as the arrivals of cruise ships are focused on old town and city ports. In accordance with the greater requirements imposed by nautical tourism, and especially by great world cruising, profiles of old town ports in Croatia, the Mediterranean and Europe are changing more and more dynamically every day [1].

The significance of old city and town ports is dynamically changing and at present, we are witnesses of new trends. Under the pressure of developing nautical tourism, these old ports are becoming a matter of interest for great cruise ships and nautical tourism in its broader meaning [2]. Thanks to its exceptional results, nautical tourism is increasingly supplanting the existing traditional activities within town ports, forming a new profile of town ports.

Even if profiles of town ports, which are more or less similar in all old ports, do change, they are in any case specific for any port. Each port has developed its own profile according to its long-term interests. Even though in the scientific literature of strategic management [3], there are not many papers dealing with the long-term management of local development, the management of town ports has, in practice, been performed in a controlled way. Local authorities have had a significant impact on the existing profile of old ports and this development has been over the centuries submitted to the local management [4].

In the planned scope of micro locations for nautical ports development in urban cities, the key role is given to physical plans of Counties [5], which are in position 
to decide about procedures of physical development. According to authors, this position gives a responsibility to local authority, especially Counties, and also integral and interdisciplinary approach in their governance [2, 6, 7]. This aim emphasises the necessity to improve co-ordination and include all relevant subjects into programmes, projects and plans [6]. It is also very important to respect the special component as early as in the preparatory stages, so that all aspects and possible effects of the intervention in the area are considered in due time, with possible conflicts avoided [8].

\section{The analysis of city ports development}

City ports are always in the function of the city development, and this development is profiled according to the development concept and model that the broader and narrower community determines. In this way, city ports on the Adriatic coast are developed so that one dominant activity is replaced by another, and the one that was dominant is transferred to the other, new and less attractive location and is replaced by a new one in the city port waters [9].

The value of waters and the coast of old city ports along the Croatian Adriatic on one hand, and the even more emphatic demand for nautical tourism, especially of cruising, on the other hand, indicates that a port as a resource requires a responsible management. The Croatian coast, at more than $5,800 \mathrm{~km}$ of a very indented Croatian Adriatic coast, has more than 750 bays, ports and marinas. It is estimated that about 104,000 vessels that are registered in Croatia in 2006, use approximately 300 ports and marinas for their seasonal or annual accommodation. The number of vessels up to today is in constant growth. At the moment, no one is taking care of this potential in an organized way. This even further intensifies the problem of maintenance and a controlled use of natural resources and their management.

Understanding the development of nautical tourism in city ports should be based on the city concept which is a complex economic and social system and a destination of numerous advantages and attractions [10]. It derives from the fact that nautical tourism in urban areas has a special significance due to direct and indirect benefits that it brings along and the strong social and cultural influence on the destination [11].

Taking into account the purpose of the area, the methodology of the multicriteria analysis has to be applied in selecting locations for nautical tourism ports in the area of Split and Rijeka. Using the methodology of the multi-criteria analysis examination of all relevant criteria, natural, environmental and economic ones is enabled, as well as the holistic approach in considering appropriate benefits of certain locations.

\subsection{The Port of Split}

The Split-Dalmatia County is spatially the biggest Croatian county with its area of 14,045 square kilometres (out of which 4,572 square kilometres of mainland). 
The County is located in the central part of the southern Croatia, on the area of the historical region of Dalmatia.

A dominant role in the Split-Dalmatia County has Split (188,694 inhabitants) which is the County's centre.

The Port of Split has transformed into the largest passenger port, in which catering and city tourism prevails. Today, in the city port, various activities exist, which do not belong to this space and are incompatible with the port area from the viewpoint of work, economy, ecology, city-planning and aesthetics [12].

The Port of Split is one of the largest and oldest ports on the Croatian coast of the Adriatic Sea. The port, which dates back to approximately two thousand years, has passed through numerous developing phases and performed many roles for the city, from providing protection from enemies from the sea, to being a trade and traffic center and ideal area in which, in recent years, the Split Boat Show, the largest business and exhibition convention of such kind in southern Europe and one of the largest tent nautical shows in the world, takes place.

The Port of Split is especially important as a junction for all types of transport. In addition to maritime and road transport subsystems, the City Port area is connected with the broader region by other transport subsystems (railway, air travel and telecommunication subsystems) into a single transport system. Passenger and cargo transport is optimally distributed across all transport subsystems.

The Port of Split is located in the central part of the Croatian coast to which many inhabited islands gravitate. It is situated on the transport corridors between Rijeka and Dubrovnik, as well as Split and Zagreb, and Ancona and Pescara in Italy.

There are several nautical tourism marinas in Split, and ACI marina Split is the biggest one with more than 400 berths (figure 1).
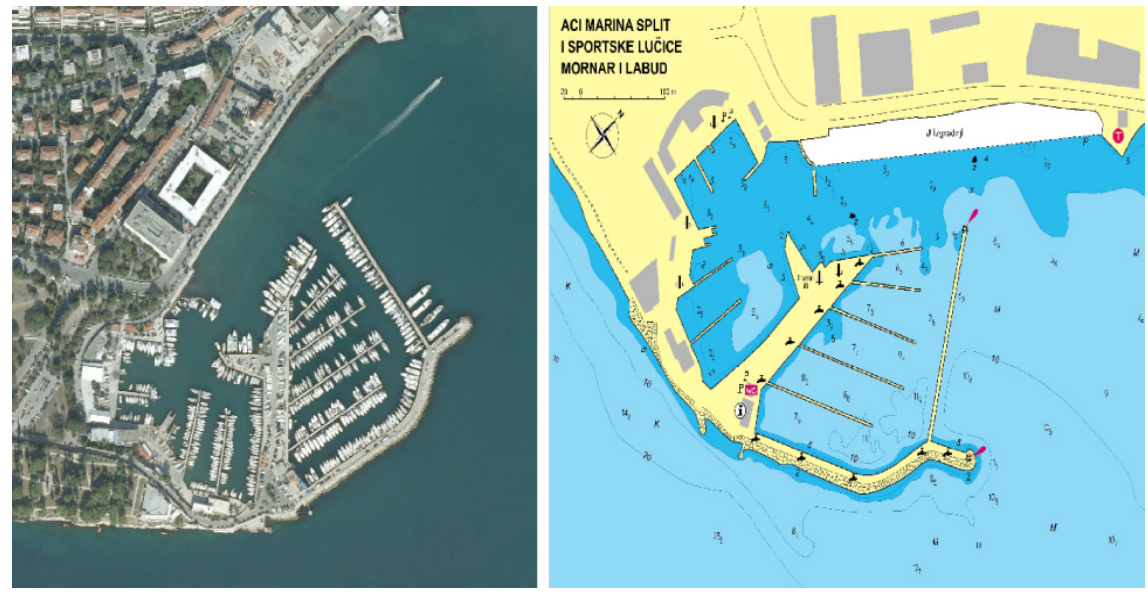

Figure 1: ACI marina, Split. 
There are two smaller nautical marinas in the western part of Split City Port where services of municipal berths are offered.

A research on five micro-locations was carried out while selecting appropriate locations for marinas in the area of the city of Split. Criteria and sub-criteria were defined, locations were evaluated and implementing the multi-criteria analysis locations for marinas for larger vessels were selected. The analysis covered the fundamental questions about the most favourable locations in the multi-criterion sense (accepting other criteria on other appropriate levels) according to the following sequence:

- With an appropriate number of berths for yachts

- With an appropriate depth of the sea

- Safety and navigation conditions

- With the best offer

- With the relatively lower construction costs, and

- Acceptable indicators for other characteristics.

The results of the analysis indicate that recently planned locations were well selected.

Planned nautical tourism marinas according to the existing Physical Planning in the city of Split are the nautical marina Žnjan with 400 berths, Poljud with 250 berths and Špinut with 150 berths. New nautical marinas, except offering berths, would also contribute to the development of Split as a nautical destination. The city's rich cultural and historical heritage and its gastronomic offer are an additional motive for boaters to stay in the city. Even though Split is known as a desirable nautical destination, without construction of new berths that would provide accommodation for vessels, especially of the ones above 10 meters in length, nautical tourism cannot have a stronger development.

\subsection{The Port of Rijeka}

The Primorsko-Goranska County has a sufficient number of berths for vessels. A larger number of smaller marinas and several bigger city ports are located along the County's area. Even though it has one fourth of the overall number of available berths in Croatia, the fact is that the existing offer of dry berths and the ones in the sea is not sufficient, so it is necessary to plan locations for an organized acceptance of berths, or it is necessary to redesign the existing city ports in marinas.

The city of Rijeka is the centre of the Primorsko-Goranska County which has 305,000 inhabitants, out of which 144,043 inhabitants has the city of Rijeka. It spreads on the area of 44 square kilometres. To the west of Rijeka is located the Opatija Riviera, the oldest and the most elite Croatian tourist region, and to the east the Crikvenica-Vinodol Riviera is located. The area that the city of Rijeka covers is unique and full of varieties in many ways. One big advantage of Rijeka is its location. It is located in the centre of Kvarner, near developed tourist destinations, from which it stands out in its own way. The city has a unique combination of traditional and modern life style and the serene and bustling rhythm. Rijeka has been developing its tourists offer in various fields for years but it is still growing as an international destination [13]. 
Less than fifty years ago, railway, maritime and bus transportation, later followed by air transportation intersected in the town port. Transhipment of cargo from vessels into railway trucks was performed on the seashore, only a few meters from the sea. The port was subjected to all branches of traffic. By developing maritime traffic and strengthening the city as transit tourist town, passenger and tourist traffic gradually supplanted the transhipment of bulk and heavy cargo from the city port. In order to disencumber the old city port, the new transhipment Northern Port with equipment for transhipment was built and in this way it drawn abreast of the Port of Rijeka paving the way for the new development of the old city port; all such activities have been carried out by city authorities in their plans.

Rijeka, that is its port, is a place where mainland and see ways cross. Former development of Rijeka and its port, the advantage of its geo-traffic position, built port infrastructure, existing traffic and business connections, the possibility for further benefits of its position and advantages to gain adequate development benefits for Croatian economy ask for considerably different policy of port development.

At the end of 2009, a part of the new and modern maritime and passengers' terminal was finished and opened. The capacity to accept vessels and passengers was slightly increased and the problem of parking lots and the separation from the cargo terminal were partially resolved. Besides the physical appearance of the terminal, its equipment is essential, which Rijeka's terminal, although new, cannot offer. Due to its traffic significance and connections, Rijeka is still active, but not enough to have social and economic benefits itself and to boost development of the region.

Nautical tourism, although long time recognized in physical plans and visions of the City, still hasn't been sufficiently valorised while identifying several potential locations. A detailed plan of the City defines four locations for nautical tourism marinas [14]: shipyard Akademija (a new port) with the capacity of 150 berths (area of 24,515 square meters), location Kantrida with the capacity of 100 berths (area of 20,352 square meters), an extension for 50 non-commercial and 50 commercial berths for repair in the shipyard Kantrida, Brajdica (new harbour) with 250 berths (area of 36,895 square metres) out of which approximately 170 are commercial and 80 non-commercial berths, and Baross with the capacity of 250 berths (area of 92,892 square meters) within the pool boundaries of Baross port area, for larger vessels.

In the very centre of the city, in the area of the city port, a nautical marina has been foreseen many years ago on the model of Mediterranean marinas. Due to various interests, its construction with accompanying hotel and other facilities still isn't a priority.

Looking at the maritime history of the city, that is becoming one of the most significant Adriatic ports by building port capacities, it can be seen that the city life has completely been transferred from the coast. Today, due to the fact that port facilities are being transferred to other locations, the opportunity for a greater turning of the City towards the sea arose. Looking at the part of the port of Rijeka located on mainland, it can be seen that with transferring the terminal and the commercial part in the port area, the area for nautical tourism marinas is created, 
like in the Mediterranean ports (Barcelona and Genoa). The area for another appropriate location would be free if the existing parking would be relocated from the coast to a multi-storey garage. That area would be used for entertainment, catering, hotel and shopping facilities. In that way, in waters near the city's waterfront, an attractive city marina could be built for vessels up to 20 meters. That complex, together with the marina for mega yachts in the partially separated marina for mega yachts in the area of Porto Barosso, would make a unique attractive coastal complex (figure 2).

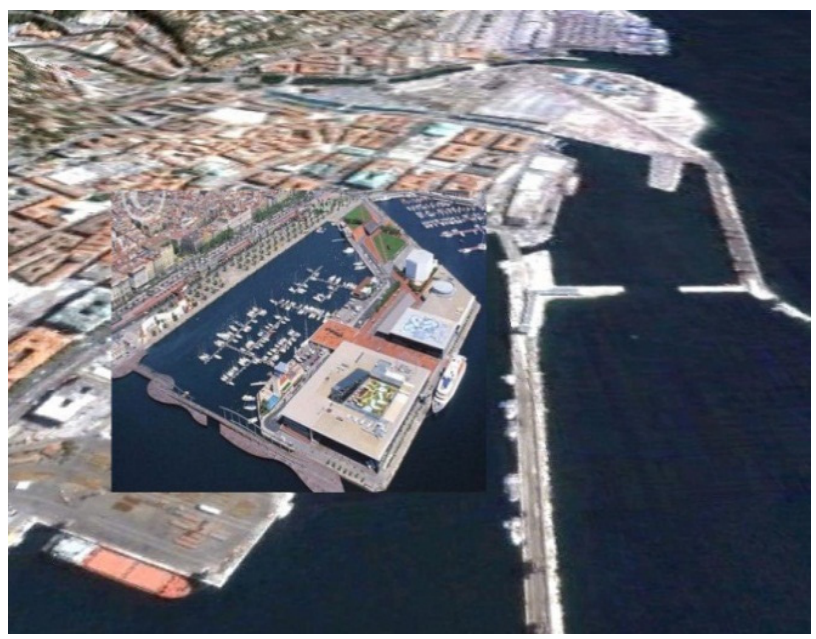

Figure 2: The vision in front of the Caroline of Rijeka pier.

The construction of such a complex would have a multiple synergic effect:

- Through the creation of new economic facilities

- Through the accessibility of the coast for residents of the city - the waterfront without cars, and

- It would contribute to the raise of the attractiveness of the city of Rijeka as a tourist destination.

Together with well-organized all-day tourist offers in the marina located in the very centre, this project would definitely profile the city of Rijeka into an attractive tourist destination.

A research on four micro-locations was carried out while selecting an appropriate location for the marina in Rijeka. Criteria and sub-criteria were defined, locations were evaluated and implementing the multi-criteria analysis locations for marinas for larger vessels were selected. The analysis covered fundamental questions regarding the most favourable locations in the multicriterion sense (accepting other criteria on appropriate levels) as well as the city of Split.

The results of the analysis indicate that the planned locations are well selected but among all these locations the location of Porto Barosso stands out. 


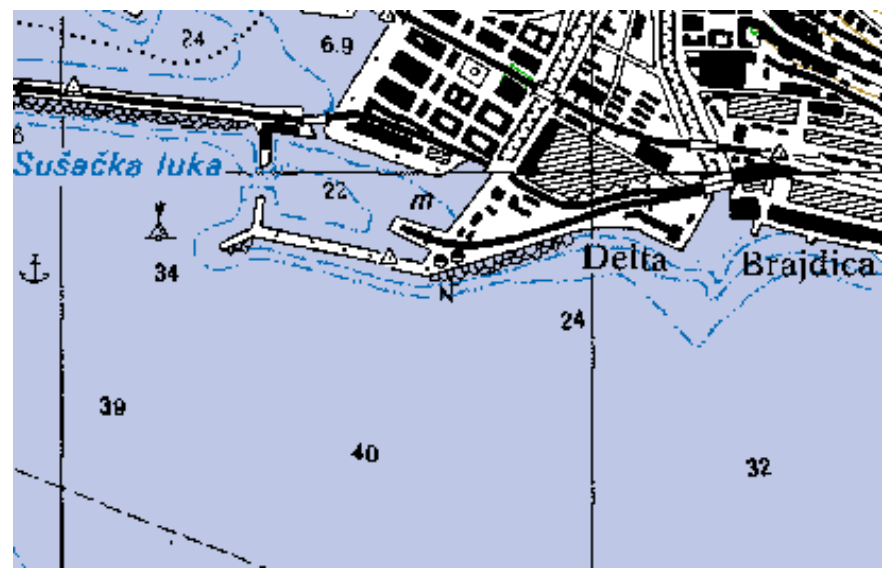

Figure 3: Cartographic view of Marina Porto Barosso, Rijeka.

\section{Results and discussion}

The achieved level of development of nautical tourism in the Split-Dalmatia County and the Primorsko-Goranska County indicates similarities and a long maritime tradition but it also indicates differences that can be seen in the strong development of tourism in the Split-Dalmatia County, and the remains of the industrial development in the Primorsko-Goranska County.

Nautical tourism in both counties has had a real development with regard to natural and other possibilities. A systematic approach in planning development in certain areas is essential, especially in Split and Rijeka, always having in mind the functional connectivity of the whole observed area.

The general principles to be applied in the planning of nautical ports require an analytical approach. Business planning nautical port in city ports must be practical and for several years ahead must anticipate the possibility of increasing capacity and improving the work of nautical port (sizes waters, the continental part of the disposal of vessels and perform a variety of activities - service, etc.). The area of a nautical port must be in accordance with the development of a city or community, so when planning infrastructure and superstructure it should be taken into account their maximum efficiency.

At the same time, the use of the multi-criteria analysis doesn't just mean the selection of the appropriate location, but it also enables the proper evaluation of the area and its suitability to locate the marina.

Carried analysis for constructing marinas on city locations in Split and Rijeka indicate a poor communication (interaction) between cities with nautical marinas, i.e. public administration and investors that primarily come from the incomprehension of various interests that at first may seem different:

- a nautical marina, especially a marina as a business entity is oriented towards convenience, productivity, competition on the market and management development 
- $\quad$ a city/place/municipality as a community of residents, are oriented towards the promotion of the well-being of citizens and the life quality, and that is why they aspire to ecological and visual values and expectations of people (residents).

Such different division leads to conflict that make physical and functional purpose of the area questionable.

Social and demographic consequences of building nautical marinas in Split and Rijeka would generally be positive and could be summarized in the following way:

- nautical marinas would be elements of attraction in the total tourists offer; they would be a supplement of the existing infrastructure and would certainly give a new quality in the urban and ambiance sense;

- they would have a positive impact on the growth of the level of employment;

- additional benefits would be created that are significant both on the local level and for the region through economic and other effects.

Marinas would contribute to the overall life quality of citizens.

\section{Recommendations}

Today's outbound pulses of markets and demands that are focused on cities ports on the Croatian coast indicate that nautical tourism is very interested in the Croatian city ports. This interest is registered in all branches of nautical tourism and the more aggressive demands are coming from the cruise market. The classical form of management has to be substituted by new local and regional strategic management which shall ensure long-term sustainable development not only of ports, but also of all directly or indirectly linked subjects [15].

The new management model should be based partner relationships of interestlinked partners. One of the most recent, simple, as well as efficient models of this relationship is the so-called private and public partnership linking private capital of an interested investor and local, regional and State administration in this investment partnership. According to the authors Žuvela and others $[2,8,10,16$, 17] who try to find suitable solution for solving the exist problem, the first good results of this model still do not indicate that this is a largely applied model. Where town ports are concerned, it is necessary first to define the competent subjects of the development model of sustainable development. The development model needs to be adjusted to these subjects and their targets and it should be used to develop a quality communication and long-life education of subjects in order to accomplish the expected results and secure the long-term sustainable development of ports.

\section{Conclusion}

The Croatian model of city-port development points to dynamic changes occurring on a limited area of the port in which the domination of one activity is superseded by another. The problem of location value and valorisation remains, in the long term, is strictly determined by the fact that there is no other alternative to the 
location of the town/port nucleus. This development model does not provide for the diversification and dispersion of the offer and location.

Maritime ports are a part of larger cities and the most attractive and valuable areas. The development of ports in Croatia and along the Mediterranean has followed the development of coastal cities. During the history, city ports changed their economic role and profile adapting to needs of the market and the city. The development of nautical tourism put a lot of pressure on old ports by changing their profile. City ports of large cities and towns have been in the function of maritime traffic, transport of people, cargo and commerce for ages. Further development of nautical tourism requires the change of a classic profile of city ports so that ports for maritime traffic are partially converted to nautical tourism ports.

\section{References}

[1] Dowling, Ross K., Cruise Ship Tourism, Joondalup, Cowan University, the Faculty of Business and Law, School of Marketing, Tourism and Leisure, 2006.

[2] Luković T., Kovačić M., Town Ports and Nautical Tourism, Faculty of Maritime Studies Rijeka, University of Rijeka, Pomorstvo - Journal of Maritime Studies, year 21, No. 2, 2007.

[3] Moutinho, L., Strategic Management in Tourism, Zagreb, Masmedia, 2005.

[4] Kovačić, M., Luković T., Spatial Characteristics of Planning and Construction of Nautical Tourism Ports, Geoadria, 12, 2007, pp. 131-147.

[5] Šimunović I., City in a Region or a Regional City, Logos Split, Croatia, 1996.

[6] Šimunović, I., Planning or the Right on the Future, Marjantisak, Split, 2005.

[7] Štimac M., Spatial Planning in Practice, Glosad.o.o., Rijeka, 2010.

[8] Favro S., Kovačić M., Physical Plans in Managing Sea and Coastal Area, 25th International Conference on Organizational Science Development, "Change management", Portorož, 2006, pp. 1049-1058.

[9] Jugović A., Kesić B., Jakomin I., Organization and Development of Maritime and Passenger Ports, Informatologia, 40, 2007, pp. 146-152.

[10] Rallo, B., Marinas in Commercial Harbors: Beyond a Neoromantic Approach, IMC 2005, Panel 14: A Marinas as a Valuable Part of Commercial Ports and Harbors, Library ICOMIA, www.icomia.com/library/

[11] Bizzarri C., La Foresta D., Yachting and pleasure crafts in relation to local development and expansion: Marina di Stabia case study, 2nd International Conference on Physical Coastal Processes, Management and Engineering, Coastal Processes, Naples, Italy, WIT Transactions on Ecology and the Environment, Volume 149, 2011, pp. 53-61.

[12] Lučka uprava Split (Split Port Authority); www.portsplit.com, 20/01/2015.

[13] The City of Rijeka, Economic Development Strategy of the City of Rijeka, 2008. 
[14] The City of Rijeka, Draft decision of making amendments of Detailed Development Plan, City Department of Development, Urban Planning, Ecology and Land Administration, 2010.

[15] Sumpor M., Is there any Institutional Capacity for Integrated Regional Development? Application of New Governance Approaches in Croatia, Local Governance and Sustainable Development, Torre A. (Ed.) Paris: European Regional Science Association; Institut National de la Recherche Agronomique (INRA), Paris; Ecole Supérieure des Sciences Economiques et Commerciales (ESSEC) Paris, 2007.

[16] Žuvela, I., The concept and strategy development of the maritime economy of Croatia, Rijeka. Pomorski zbornik, 38(1), 2002.

[17] Kovačić, M., Dundović, Č., Planning and design of nautical tourism ports, Rijeka, the Faculty of Maritime Studies, the University of Rijeka, 2012. 